Article

\title{
Situating Poligen Studies: Between Moral Enquiry and Political Theory
}

\section{Réal Fillion}

Department of Philosophy, University of Sudbury, Sudbury, ON P3E 2C6, Canada; rfillion@usudbury.ca

Received: 13 November 2017; Accepted: 24 December 2017; Published: 27 December 2017

\begin{abstract}
In this article, I argue that we can best appreciate those works that appeal to the notion of "political genealogy" as distinct forms of study by situating them between moral enquiry and political theory. They draw from moral enquiry the concern with how we ought to live but are not themselves prescriptive. They address the political constitution of our social lives but not as a theoretical object. Reversing the relation between enquiry and truth, political genealogies are historiographical studies motivated by forms of resistance that expose the will to truth of the present ordering of discourses, thereby releasing the hold such orderings have on what we think, say, and do to their on-going agonistic relations.
\end{abstract}

Keywords: discourse; ordering; truth; enquiry; subversion; Foucault; MacIntyre; historiography; resistance; possibility

Joining my colleagues on the picket line in support of their work action (my own federated university has its own administration and, though we teach the same students, we are under a different collective agreement), I was afforded an interesting opportunity to appreciate what brings us together as academics, even as it divides us. This particular strike was occasioned by the declaration of an "impasse" in negotiations by the administration just before the strike deadline. As universities are increasingly administered by organizational principles and people only tangentially connected to the performance of academic work per se (defined in North America as research, teaching, and community service), such declarations of "impasse" should no doubt be expected, as both parties increasingly are faced with forging workable language to continue doing what each thinks it is its job to do. Given the administration's apparent conception of the relation between research and teaching (proposing that ostensibly measurable lower research output should be redressed with increased teaching loads), for faculty the hugely diverse character of what counts as actual academic work took second place to a rallying resistance. But, of course, as conversations amongst ourselves eventually moved beyond the immediate circumstances, the differences within academic work resurfaced, and the divisions within the academy and its various discourses reconfigured the conversational partners along familiar lines even as we all walked and stood the line, solidarity sporadically reaffirmed by the honking of passing cars.

This was especially marked for me because I was not myself on strike-that is, I continued to be paid my regular salary, as opposed to strike pay-and yet all classes on campus were suspended, effectively putting a stop to my own teaching, and releasing me to my other duties, which for most of us meant our research which may or may not include contact and communication with various communities. This is not as simple a situation as it sounds, given the various ways academics can divide up the time to pursue these different activities, blocking research around particular periods of the year, outside of the teaching schedule, for example (as often happens in largely undergraduate institutions like my own). As it turns out, the suspension of my teaching did have the fortuitous effect of allowing me to focus my attention on this particular article. But thrown together on the picket line, I was reminded how peculiar it is to explain to my (immediately) fellow academics the kinds of lines of 
enquiry I pursue. Walking alongside some of my colleagues from the sciences and engineering, saying that I was working on an article on Foucault would pretty much cover the extent of my explication, unless they were polemically informed and inclined. Pockets of colleagues from other disciplines, already self-selected into groups by interdisciplinary projects and concerns, might be receptive to the particular focus on political genealogy and questions might be asked, some of them still slightly polemical, but others more engaged and substantial.

Indeed, as I chatted with various colleagues and scanned the assembled group, I realized that the work that many of them do might very well be implicitly allied with what Clifford (2013) has termed "poligen studies," that is, a distinct mode of study which, albeit with various points of departure, can be discerned through asking the following questions: "does [the work in question] give us a plausible understanding of the historical origins of the area it is examining? Furthermore, is this understanding disruptive of the way that we have heretofore understood ourselves and the world? Does it point toward the possibility of being other than we currently are?" (Clifford 2013, p. 123). I say that some of their work might be implicitly allied because their own discursive commitments might not lead them to characterize their efforts as explicitly genealogical, though they would no doubt appreciate their political character, and this along the lines proposed by Clifford, that is, as "disruptive" and "other" to the prevailing discursive commitments of many of their colleagues in the university and society at large. What then would be required for their work explicitly to participate in "poligen studies"? The most obvious thing to say, if we reference the questions posed above, is that they would need to pay explicit attention to something like the "historical origins" of what concerns them. That is, they would need to see that their concerns fall within the historical parameters of a distinctly constituted dissatisfying present, a present that contains and maintains features that ought not to be the way they are and that are nevertheless somehow sustained in their being as they are. We can see, then, that such studies have an implicit moral concern with what ought to be, with how we ought to live; however, as forms of study the explicit concern is with the historically determinable conditions of how we do in fact live with and within the terms of this present.

With this focus on a distinctly constituted dissatisfying present, my suggestion will be that we can situate poligen studies between moral enquiry and political theory. I say "between" because, though the kinds of study that we might qualify as political genealogies do address the moral questions of how we ought to live, they do so indirectly. As such, they themselves are not strictly speaking moral enquiries but rather investigations or studies that challenge or disrupt the discourses and practices that arguably do provide answers to those moral questions of how we ought to live. As well, though these investigations or studies are deemed "political," their object is not the political understood as some kind of timeless feature of social life and as such their objective is not to produce nor to rely on a "theory." Like the moral (or morality), the political is approached indirectly, not through theoretical elaboration as an object, but through a studious disruption of the discourses and practices that are said to constitute it as the present, a discernably distinctive historically specific configuration of relations of power.

The sense of the "between" here is thus spatially imagined. Such studies situate themselves as distinct from, though related to, both moral enquiry and political theory. However, there is another reason for situating them here, perhaps "betwixt" is the better word, as their distinctiveness nevertheless depends on these contrasting concerns and, I will be arguing, they are subject to the pull of both. The resultant tension is creative, but also difficult to sustain, with the danger of the relevance of such studies giving way to mere moral exhortation or being replaced by largely politically ineffective theorizing.

That poligen studies should be akin to political theory should be obvious given their explicit qualification as political. Such explicitness serves to inflect their genealogical approach from Nietzsche (2006) original study (and targeting) of morality, expanding its scope to discursive formations more generally conceived (and, once again following Clifford $(2001,2013)$ following Foucault, as these discursive formations connect to power relations and practices of self-formation) and favoring an 
approach that is perhaps less polemical in presentation and more focused on illuminating the conditions of the intelligibility of the present. That is, while Nietzsche (1997) meant to show us the "uses and disadvantages" of the appeal to history for life, including a critical history that serves life by sometimes being "clear as to how unjust the existence of anything — a privilege, a caste, a dynasty, for example-is, and how greatly this thing deserves to perish" (Nietzsche 1997, p. 76), the focus of political genealogy is less on "life" than on the present. However, the intention to "disrupt," indeed to subvert, remains central, though if we think of subversion here not merely as undermining an established order, but etymologically as a kind of "overthrowing," a "throwing over from below," we might consider its genealogical version as a "throwing off" of the constraints definitive of our present discursive ordering. This subversive intent is no doubt what links Nietzschean and Foucaultian genealogy. Before exploring the particular political inflection of Foucaultian genealogy further, I suggest we consider genealogy as a mode of moral enquiry for a moment so that we can better discern the distinctiveness of an explicitly political genealogy, but also so that we can better discern the pull and purpose that moral enquiry will continue to exert on the situating of poligen studies.

Alasdair MacIntyre (1990) qualifies genealogy as one of three rival versions of moral enquiry, the other two being "encyclopedia" and "tradition." While this might appear to be a somewhat idiosyncratic parsing of the field of moral enquiry, it is actually quite illuminating, especially as I think back to the conversations with my colleagues on the picket line. All of my academic colleagues are engaged in enquiries of some sort. This is what we mean when we say we are engaged in "research." Not all of them, indeed perhaps not many of them, would qualify their enquiring engagement as "moral," and yet it is not implausible to do so, given that what they do is connected to the question of how we ought to live. If they were on strike, it was because their conception of the work that they do contributes to the way they believe we ought to live, which includes "the pursuit of knowledge" through their research, and that subordinating that research to administratively determined financial priorities was morally unacceptable (i.e., not how we ought to "pursue" knowledge). That such an appeal to the morally unacceptable should remain largely implicit is part and parcel of the particular mode of moral enquiry MacIntyre calls "encyclopedia," arguably the typical or predominant mode informing the discursive practices that make up the academy, inasmuch as the academy as a whole-and insofar as it considers itself as a coherent whole, as my striking colleagues surely did, at least under the circumstances-commits itself to something it calls "rationality" or rational enquiry.

MacIntyre calls this particular mode of moral enquiry "encyclopedia" because "morality" is treated not (explicitly) as something that informs our lives as a whole but rather qualifies certain judgments we might make within the broader context of a "rational" appreciation of ourselves and the world: that appreciation, ideally-conceived, would be captured "encyclopedically," divided into various entries as it were, and serving as the common reference of our knowledge. Something like this common "encyclopedia" of knowledge is what unites all enquirers in their endeavors, in their common "pursuit of knowledge." As MacIntyre puts it: “The encyclopedist's conception is of a single framework within which knowledge is discriminated from mere belief, progress towards knowledge is mapped, the truth is understood as the relationship of our knowledge to the world, through the application of those methods whose rules are the rules of rationality as such" (MacIntyre 1990, p. 42).

Moral judgement-determining what is right or wrong-within this broader context of rational enquiry is for each of us to make and, if it is to be assessed, then it is to be assessed by rational criteria, theoretically devised: how the action it proposes contributes to the greatest good of the greatest number, or how it respects an imperative that is categorical, for example. The problem with this approach, which MacIntyre $(1984,1988)$ has long been at pains to point out, is that the rational tests proposed by "morality" theoretically conceived do not yield agreement but rather intractable disagreement, albeit in a way that curiously does not expunge the conception of rationality that informs them. Part of the reason for this, I would argue, is that on the encyclopedic conception of ourselves and the world, rationality remains the explicit reference, and lives governed by explicit rules and laws (the articulation 
of which are the hallmarks of rationality) prove themselves to be sufficiently orderly and stable to allow for such merely "moral" disagreements.

Not all of my colleagues on the picket line would subscribe to this account of "morality," other than —and this should be emphasized-recognizing that the determination of right and wrong is a judgment for each of us to make. Many of them would see in the rational ordering of explicit rules and laws much to condemn from a moral point of view (of how we ought to live) and would appeal, not to rational tests, but to various forms of action (including forms of study) protesting the so-called rational ordering in question. It is this subversive intent with regard to the dominant ordering of the social world that opens the possibility of connecting the work of these colleagues to a different conception of moral enquiry, one that MacIntyre describes as "genealogy" and distinguishes it from "encyclopedia" and its relation to (rational) truth and the world. Privileging Nietzsche's account, this approach "takes there to be a multiplicity of perspectives within each of which truth-from-a-point-of-view may be asserted, but no truth-as-such, an empty notion, about the world, an equally empty notion. There are no rules of rationality as such to be appealed to, there are rather strategies of insight and strategies of subversion" (MacIntyre 1990, p. 42) ${ }^{1}$. What makes these approaches radically different (and rivals on MacIntyre's view) is how they relate enquiry and truth. For encyclopedia, enquiry purportedly subordinates itself to truth; for genealogy, truth is subordinated to enquiry, truth revealed upon investigation to be in effect supported by the will to truth through the imposing of particular discursive orderings (including determinations on how we ought to live). Showing this to be the case requires strategic interventions within those discursive orderings.

But what, if anything, might be seen to guide such strategic interventions? Simply another will, Nietzsche's will to power? One might be tempted to see in my example of striking colleagues precisely this, less a moral judgment about how we ought to live, and more a question of the relative power of faculty and administration when it comes to determining the conditions of what each does. But this is to oppose moral judgment and power relations, an opposition that builds on the isolating of "morality" from the unfolding of our lives, something promoted by the rational (encyclopedic) appropriation of the term, which MacIntyre reminds us does not have this independent status in pre-modern languages, the moral being folded into the descriptive comprehension of social life (mores, ethos). I agree with MacIntyre that this opposition should be resisted. My striking colleagues were indeed engaged in power relations, but their moral judgment of how we ought to live was no less present in their actions and their actions a function of their agency. What "genealogy" does, at least as practiced by Foucault, is precisely to focus on the power relations involved in these interactions between various agents, where their "freedom" as agents shows itself to be inflected in distinct ways. ${ }^{2}$ This distinctiveness becomes apparent from the point of view afforded by the presence of resistance within these power relations. As Foucault (1982) puts it, a genealogical approach "consists of taking the forms of resistance against different forms of power as a starting point.... it consists of using this resistance as a chemical catalyst so as to bring to light power relations, locate their position, and find out their point of application and the methods used. Rather than using power from the point of view of its internal rationality, it

1 Clearly not all of my colleagues critical of the dominant political ordering of the world will see themselves in such a genealogical perspective, many preferring instead to reference the notion of human rights. How the notion of human rights fits into either MacIntyre's parsing of moral enquiry or how it relates to political genealogy more generally is beyond the scope of this paper. For an interesting discussion of the paradigm of human rights, cf. Moyn (2010).

2 That, for Foucault (1982), the exercise of power and agency as freedom mutually imply each other is clear in the following oft-cited passage: "Power is exercised only over free subjects, and only insofar as they are free. By this we mean individual or collective subjects who are faced with a field of possibilities in which several ways of behaving, several reactions and diverse comportments may be realized. Where the determining factors saturate the whole, there is no relationship of power; slavery is not a power relationship when man is in chains. (In this case it is a question of a physical relationship of constraint.) Consequently, there is no face-to-face confrontation of power and freedom, which are mutually exclusive (freedom disappears everywhere power is exercised), but a much more complicated interplay. In this game freedom may well appear as the condition for the exercise of power (at the same time its precondition, since freedom must exist for power to be exerted, and also its permanent support, since without the possibility of recalcitrance, power would be equivalent to physical determination)" (Foucault 1982, p. 790). 
consists of analyzing power relations through the antagonism of strategies" (Foucault 1982, p. 780, my emphasis). Therefore, to the question of what guides strategic genealogical investigations, the answer is to be found in actual resistances within the discursive orderings of our present society. As Foucault immediately suggests (where we recognize his own work): "to find out what our society means by sanity, perhaps we should investigate what is happening in the field of insanity. And what we mean by legality in the field of illegality" (Foucault 1982, p. 780).

But here is where I would suggest that specifically Foucaultian genealogical investigations are something other than MacIntyre's "rival version" of moral enquiry. MacIntyre's basic claim (MacIntyre 1984) is that moral enquiry today is a fractured affair, that the development of "morality" as a distinct dimension of human life (captured in moral judgments about how we ought to live) was a consequence of its severance from the unfolding of our whole lives (whose wholeness Aristotelian philosophy and then Christian theology had better captured). On MacIntyre's account, this severance has resulted in a truncated "rationality" confronting an indifferent world grasped through observed regularities with its "morality" of (dis)agreement on the one hand, and a rejection of any graspable "timeless" truth in favor of a project of disordering subversion on the other. Thus "encyclopedia" and "genealogy" are rivals to each other in their distinct relating of enquiry and truth but also rivals to a conception of moral enquiry as integral to the living wholeness that MacIntyre calls "tradition." For MacIntyre, "tradition" names the argumentative context within which a moral enquiry into how best to realize the Good takes place, a Good that the potential enquirer first takes as given (as real) and thus, in becoming an actual enquirer into that Good, only then seeks to know it. In MacIntyre's account of this rival version of moral enquiry, the real object becomes the enquirer him or herself and his or her relation to the Good and the authoritative tradition that creates an argumentative space for this enquiry to take place, where disagreements are articulated against a background of agreement. The critique of genealogy from the perspective of this rival version of moral enquiry thus targets the genealogist whose subversive purpose is not accounted for, even on his or her own terms, given the lack of recognition of any authoritative context within which one can make sense of it; such enquiry can only appear, again on MacIntyre's view, even to the genealogist him or herself, as arbitrary.

However, I would argue that this apparent arbitrariness is not a function of the genealogist's own subversive purpose, but the very real effect of ordering discourses themselves as seen from the perspective of that which resists them. It is in this sense that a genealogy that focuses on the present does not pretend to be a form of specifically moral enquiry, interestingly largely because, like MacIntyre's account of "tradition," it can be said to treat "morality" not as its own distinct sphere (and tied to discreet judgments) but as incorporated into social life more generally. Unlike "tradition," however, it does not see the "good" that is realized through the practices of social life as having a "timeless" source and an independent "truth." MacIntyre's critique of the genealogical project, with its focus on the genealogist's accounting for him or herself of the very point of his or her enquiry, is not without merit, as far as conceptions of the moral self are concerned (something to which Foucault, for example, turns his attention in his discussions of self-formation in his later works); however, this critique does not address the fact that the ordering discourses of social life are resisted and that such resistances open up a possible perspective on their character as distinctly constituted and imposed ordering discourses. These real resistances to the imposed character of ordering discourses are the real and actual sources of the possibility of genealogical subversion, and not the arbitrary purpose of any given genealogist. Or so I would suggest, following Foucault's development of a more political genealogy.

What distinguishes genealogy as a form of enquiry, then, is that it reverses the relation between enquiry and truth: enquiry is not subordinated to an independent truth, truth itself becomes subject to enquiry. In this reversal, truth becomes "truth" and its effects come under scrutiny. "Truth" circulates in the ordering of discourses and it impacts on what is thought, said, and done. It has effects. As mentioned above, such effects as effects are evidenced in the resistances to the ordering of discourses, especially as these discourses coalesce around those kinds of knowledges meant to 
intervene into the workings of social life. Such interventions count as political insofar as they actively contribute to the on-going constitution of our social order; and as such, they become subject to a distinct form of genealogical enquiry from the perspective opened by attention to the resistances to those interventions. To qualify such enquiry as "genealogical" is to underscore the eventfulness of that which it is investigating, its historically determinable constitution at the confluence of discursive practices and their effects. Thus, genealogical enquiry proposes itself as a form of historiography, where history here must be understood not in terms of its object (i.e., the past), but etymologically as what it is itself, its own distinct form of "enquiry," 3 an investigation meant to provide an account of the goings-on of human affairs in their eventfulness and "impactfulness," as it were. But what makes this form of historiography "genealogical" remains the subversive intent. It is not an enquiry whose findings are meant to culminate into an account of an ordered establishing of the facts. It is not a judicial enquiry into a past event or series of events. It is a genealogical enquiry into the constituting of a present ordering that reveals its historical distinctness and lack of necessity. That is, the present order of things is discernably intelligible not because it rests on a true grasp of them but because of the discursive regularities it exhibits and maintains.

I have been privileging in this discussion the notion of discourses and more specifically the ordering of discourses. I am taking as central Foucault's L'ordre du discours (Foucault 1971), his inaugural lecture at the Collège de France. Translated into English, somewhat curiously as "The Discourse on Language," and appended to the translation of Archaeology of Knowledge (Foucault 1972), I would argue that this text can now, with the publication of all of Foucault's subsequent lectures at the Collège de France, take its central place as inaugurating the mode of enquiry he would continue to develop as "genealogy" throughout the 1970s and should be, in my view, a key textual reference for situating poligen studies themselves. In it, we find a clear expression of the subversive intent of inverting truth and enquiry, by showing how "truth" rests on both a will to truth and a will to know and to knowledge that operate by ordering discourses. Thus, the "order of discourse" is an ordering, an imposing of order through discourse, supported by a will to truth and a will to knowledge, truth and knowledge themselves given distinct status by this (willful) ordering of discourse. Foucault, near the opening of this inaugural speech (the opening of the opening discourse/lecture of the lectures he will henceforth be giving from the space of this newly self-designated Chair of the History of Systems of Thought-the Collège de France is an extraordinary institution), after fretting about this auspicious but nevertheless imposed need to begin, wonders about the institutionalized and institutionalizing, established and establishing ordering function of discourse and asks, quite simply: "What is so perilous, then, in the fact that people speak, and that their speech proliferates? Where is the danger in that?" (Foucault 1972, p. 216).

In asking this simple question, Foucault is pointing to a divide within discourse between a speech that proliferates and largely disappears or dissolves after its enunciation, and speech that, through certain forms of repetition and attention, organizes itself into discourse, into discursive formations that can be seen to operate in fact (evident when attention is paid to that which resists them) as systems of exclusion which he categorizes briefly as follows: that of prohibiting certain forms of speech (la parole interdite), that is, recognizing and reinforcing that not everything can be said; that of rejecting certain forms of speech as outside the bounds of sense and reason (le partage de la folie); and then finally that of the divide insisted on by the will to truth itself, that between the true and the false (Foucault 1972, pp. 216-19). This last divide, Foucault tells us, needs to be appreciated (if we want to account for a present that continues to insist on subordinating enquiry to an independent truth) as actually historically situated within Greek culture when, through philosophical appropriation in the fifth century, true discourse was separated from its distinct conditions of enunciation as act, as

3 "History is a Greek word, meaning simply an investigation or inquiry ... It is the use of this word, and its implications, that makes Herodotus the father of history. The conversion of legend-writing into the science of history was not native to the Greek mind, it was a fifth-century invention, and Herodotus was the man who invented it." Collingwood (1946, pp. 18-19). 
assertion (as oath and ordeal ${ }^{4}$ ) and subordinated to formalized discourse; that is, "the highest truth no longer resided in what discourse was, nor in what it did: it lay in what was said. The day dawned when truth moved over from the ritualized act-potent and just—of enunciation to settle on what was enunciated itself: its meaning, its form, its object and its relation to what is referred to" (Foucault 1972, p. 218). The effect of this relation to the "truth" as the "enunciated" (within ordering discourse) creates a distance between the conditions of enunciation and what is enunciated. Sustained and continued attention to the enunciated ends up concealing from such ordering discourse its own willful conditions of enunciation, its own desire and exercise of power, and the point of genealogical investigations is to have us confront their continued workings within discourse. That is, as Foucault writes: "True discourse, liberated by the nature of its form from desire and power, is incapable of recognizing the will to truth that pervades it; and the will to truth, having imposed itself upon us for so long, is such that the truth it seeks to reveal cannot fail to mask it" (Foucault 1972, p. 219, my emphasis). The willful conditions that sustain the enunciation of truth, by becoming the discursively enunciated formally maintained, are systematically obscured and covered over, but nevertheless remain at work.

The genealogical task before us, then, is to challenge the order of discourse and to show on the one hand the workings of desire and the exercise of power within the ordering of discourses and their delimiting or policing function of what can legitimately be said. This task is a political one, inasmuch as the ordering of discourses it addresses contributes to the constitution and the maintenance of the particular present social order. But, as political, it is not direct political action (though of course part of its point is to have its enquiries resonate within political action or political movement) but a subversive engagement with and within the given ordering intelligibility of the present; however, while this engagement with the conditions of intelligibility of the present points to political theory, the intelligibility it lays bare is not that of a discursively determined object (the constitution of the political, timelessly conceived). It is the result of historiographical enquiry aimed at disrupting the hold the ordering of discourses has on what we think, say, and do in the present and specifically the hold it has by masking the "will to truth" that sustains this ordering function. This masking does not only operate in terms of systems of exclusion, however. As Foucault goes on to say in L'ordre du discours, there are "many other systems for the control and delimitation of discourse," such as those of "internal rules, where discourse exercises its own control; rules concerned with the principles of classification, ordering, and distribution" (Foucault 1972, p. 220). He groups these systems according to distinct principles for limiting discourse (which we can find throughout the academy): those linked to key texts and producing "commentary"; a linked but distinct principle coalescing texts around the notion of the "author"; and, finally, the principle of limitation most relevant to this effort of situating "poligen studies," that of "disciplines."

According to Foucault, "disciplines are defined by groups of objects, methods, their corpus of propositions considered to be true, the interplay of rules and definitions, of techniques and tools"

4 Which the subsequent lectures will explore (Foucault 2013). Cf. also many years later the discussions of truth-telling in Foucault (2014). It is interesting to note how Foucault, in both series of lectures, themselves separated by ten years, appeals both to the same example (Antilochus' challenge to Menelaus) and sets up the discussion by quoting the same passage from Georges Dumézil's Servius et la Fortune (quoted in (Foucault 2013, p. 84)); " 'As far back as we go in the behavior of our species, the 'true utterance' is a force to which few forces resist ... very early on the Truth appeared to men as one of the most effective verbal weapons, one of the most prolific seeds of power, one of the most solid foundations for their institutions.'” Quoted in (Foucault 2014, p. 28), translated as: “'Looking back into the deepest reaches of our species' behavior, 'truthful speech' [la parole vraie] has been a force few could resist. From the earliest moments, truth was one of man's most formidable verbal weapons, most prolific sources of power, and most solid institutional foundations.'") In the lecture on 3 February 1971 (Foucault 2013, p. 85), he provides an illuminating contrast. First, there is what we easily recognize today as the uttering of truth in the form of bearing witness to something we have observed, thus serving the function of revealing to others something that has already taken place. Here the "non-verbal equivalent" of uttering the truth "is perception: showing things as if one was there, as if one was seeing them." A kind of distance is placed between the utterance and the truth of what is said. This contrasts with the earlier (Homeric) relation with truth through utterance where "the non-verbal equivalent for the word of truth is the ordeal, the test: being exposed or exposing someone to undefined danger." Here the relations between the truth, the occasion of its utterance, and the one who is challenged to utter it are much more intimate. The will to truth is more immediately present. 
(Foucault 1972, p. 222), ultimately creating the conditions for "the possibility of formulating, and reformulating indefinitely, new propositions" (Foucault 1971, p. 32, my translation). They are thus both productive and restrictive-productive of new propositions and restrictive of what can actually be said. But they are also many and arguably poligen studies also circulate amongst—and between — such disciplines, not because such studies do not wish to be pinned down but precisely because their political aim is disruptive and subversive in its attempt to capture what the ordering discourses themselves do, the effects that they have as seen from the perspective of their imposition on what we think, say, and do, the imposed ordering of the present in its contingent particularity.

How effective are such studies in disrupting the imposed ordering of present discourses? This question seems to arise here, given the stated aim. But the asking of it might be coming from the distinct discursive space of normative political theory, with its own concern of identifying and articulating the appropriate conditions of political and social order conceived theoretically, placed at a distance from the ordering function itself. Political genealogies challenge this self-distancing; they do not seek to establish nor to delimit (theoretically) such conditions, they seek to show the contingent hold such conditions actually have on what we think, say, and do and part of their purpose is to contribute to releasing us from their imposed character. Any effectiveness they might have in that regard should be measured by their ability to allow us to think, say, and do otherwise, despite and against the ordering of discourses all around us. And what that might be cannot be pre-said. That is, indeed, the point: to open the possibility of enunciation in terms other than the enunciated.

I have argued that we should situate "poligen studies" - the various studies that have engaged many scholars in a certain kind of historiographical enquiry aimed at disrupting or subverting the hold that the present ordering of discourses has on what we think, say, and do-between moral enquiry and political theory. Such studies, like moral enquiry, address how we ought to live but do so not by prescription or rational assessment but by enquiring into and exposing the contingent formation of the discursive conditions delimiting how we are actually made to live. They are thus dissatisfied historiographical studies of a distinctly constraining present. In this, their object is not the past, but the present constitution of our social order and, like political theory, they question the normative character of that constitution; however, this is done not from the space of a theoretical elaboration (which presupposes the very distance that needs to be overcome) but from the perspective opened up by the struggles and resistances that manifest themselves against the imposed character of that constitution. Another way to say this is that situating the pursuit of poligen studies between moral enquiry and political theory is to recognize that these struggles and resistances themselves express the moral refusal of the ordering constraints being imposed on the struggling and resisting agents subject to them and that this motivates the study of the emergence of such constraining orderings, understanding them to be discursively constituted in a way that masks their own disciplinary willfulness. Exposing that willfulness loosens the constitutive hold those orderings have on what we are made to think, say, and do and opens up the possibility of equally willfully (agonistically) being otherwise within and against them.

My striking colleagues were not on the picket line very long. A settlement was reached and classes resumed. Thus, in appearance the disruption was reabsorbed into the disciplinary ordering and functioning of the university, as deadlines were extended, exam periods were contracted, and work discursively re-ordered itself. But this settlement, like all settlements, is in fact a contingently constructed reality, and the disruption that occasioned it also throws light on that disciplinary ordering, exposing its present delimiting powers to further and on-going contestation, a renewed wariness of willful constraints masquerading as "necessary." It is not an easy thing to sustain such wariness, to sustain a space of contestation to the exposed willful ordering of discourse that is not merely moral outrage or critical political theorizing, but it is possible. And it is to this possibility that political genealogy commits itself.

Conflicts of Interest: The author declares no conflicts of interest. 


\section{References}

Clifford, Michael. 2001. Political Genealogy after Foucault: Savage Identities. New York and London: Routledge.

Clifford, Michael. 2013. Empowerment: The Theory and Practice of Political Genealogy. Lanham: Lexington Books.

Collingwood, Robin George. 1946. The Idea of History. Oxford: Clarendon Press.

Foucault, Michel. 1971. L'ordre du Discours. Paris: Gallimard.

Foucault, Michel. 1972. The Archaeology of Knowledge and the Discourse on Language. Translated by A. M. Sheridan Smith. New York: Pantheon.

Foucault, Michel. 1982. The Subject and Power. Critical Inquiry 8: 777-95. [CrossRef]

Foucault, Michel. 2013. Lectures on the Will to Know: Lectures at the College de France, 1970-1971. Edited by Daniel Defert. Translated by Graham Burchell. New York: Palgrave Macmillan.

Foucault, Michel. 2014. Wrong-Doing, Truth-Telling: The Function of Avowal in Justice. Edited by Fabienne Biron and Bernard E. Harcourt. Translated by Stephen W. Sawyer. Chicago: The University of Chicago Press.

MacIntyre, Alasdair. 1984. After Virtue: A Study in Moral Theory. Notre Dame: University of Notre Dame Press.

MacIntyre, Alasdair. 1988. Whose Justice? Which Rationality? Notre Dame: University of Notre Dame Press.

MacIntyre, Alasdair. 1990. Three Rival Versions of Moral Enquiry: Encyclopedia, Genealogy, and Tradition. Notre Dame: University of Notre Dame Press.

Moyn, Samuel. 2010. The Last Utopia: Human Rights in History. Cambridge: The Belknap Press of Harvard University Press.

Nietzsche, Friedrich. 1997. Untimely Meditations. Edited by Daniel Breazeale. Translated by R. J. Hollingdale. Cambridge: Cambridge University Press.

Nietzsche, Friedrich. 2006. On the Genealogy of Morality. Edited by Keith Ansell-Pearson. Translated by Carol Diethe. Cambridge: Cambridge University Press.

(C) 2017 by the author. Licensee MDPI, Basel, Switzerland. This article is an open access article distributed under the terms and conditions of the Creative Commons Attribution (CC BY) license (http:/ / creativecommons.org/licenses/by/4.0/). 